\title{
Improving photosynthetic characteristics and antioxidant enzyme activity of capsule wall and subtending leaves increases cotton biomass under limited irrigation system
}

\author{
N.N. LI ${ }^{*, \dagger}$, F. SHI ${ }^{*, \dagger}$, H.Y. GAO ${ }^{*, \dagger}$, A. KHAN", F.Y. WANG ${ }^{* *}$, X.H. KONG ${ }^{* *,+}$, and H.H. LUO ${ }^{*,+}$ \\ Key Laboratory of Oasis Eco-Agriculture, Xinjiang Production and Construction Group, Shihezi University, \\ 832003 Shihezi, Xinjiang, China* \\ Cotton Research Institute, Xinjiang Academy Agricultural and Reclamation Science/Northwest Inland Region Key \\ Laboratory of Cotton Biology and Genetic Breeding (Xinjiang), Ministry of Agriculture, 832000 Shihezi, China**
}

\begin{abstract}
The photosynthetic performance of the canopy boll-leaf system (BLS) reflects the material and energy exchange abilities between plant and external environment. A two-year field experiment determined the response to irrigation regimes $\left[600\left(\mathrm{~W}_{1}\right), 480\left(\mathrm{~W}_{2}\right)\right.$, and $\left.360\left(\mathrm{~W}_{3}\right) \mathrm{m}^{3} \mathrm{ha}^{-1}\right]$ of cotton BLS physio-biochemical traits. Decreasing irrigation, photochemical quenching coefficient, the electron transfer rate of PSII, chlorophyll, and stomata width of the BLS decreased; nonphotochemical quenching (NPQ), the activity of superoxide dismutase (SOD), peroxidase (POD), catalase (CAT), hydrogen peroxide $\left(\mathrm{H}_{2} \mathrm{O}_{2}\right)$, and malondialdehyde (MDA) contents increased at 7-21 day interval after anthesis (TAA). Among them, $\mathrm{W}_{2}$ increased SOD and POD by $3.5-42.1 \%$ and $1.4-57.8 \%$, respectively, compared to $\mathrm{W}_{1}$ treatment. NPQ and carotenoid contents of capsule wall and CAT of subtending leaves increased. Principal component analysis showed that NPQ, MDA, $\mathrm{H}_{2} \mathrm{O}_{2}, \mathrm{POD}$, and CAT were positively correlated with the seed biomass. Therefore, cotton could protect photosynthetic apparatus by maintaining lower membrane lipid peroxidation and higher heat dissipation capacity of capsule wall and subtending leaves to ensure higher biomass accumulation under limited irrigation.
\end{abstract}

Keywords: antioxidative enzyme activity; boll-leaf system; drip irrigation; stomatal structure.

\section{Introduction}

Cotton (Gossypium spp.) is one of the most important fiber, edible oil, and animal feed crops worldwide (Tang et al. 2005). According to the National Bureau of Statistics data for 2019, China's annual average cotton output accounted for $22.3 \%$ of the global output, while Xinjiang's cotton output accounted for $84.9 \%$ of the total national

\section{Highlights}

- Capsule wall increased carotenoid content and heat dissipation capacity in response to drought

- Low membrane lipid peroxidation in boll-leaf system ensures high biomass accumulation

- The stomatal density of capsule wall increased under limited irrigation
Received 12 August 2020

Accepted 10 February 2021

Published online 17 March 2021

${ }^{+}$Corresponding authors

phone: +689932058075 , fax: +869932057999

e-mail: luohonghai79@163.com (H.H.Luo) xjkxh920@163.com (X.H. Kong)

Abbreviations: Car - carotenoids; CAT - catalase; Chl $a(b)$ - chlorophyll $a(b)$; BLS - boll-leaf system; ETR - apparent electron transfer rate; $\mathrm{ETR}_{\mathrm{II}}-$ electron transfer rate of PSII; $\mathrm{F}_{0}-$ the initial minimal fluorescence; $\mathrm{FB}_{3}-$ the $3^{\text {rd }}$ fruiting branch; $\mathrm{F}_{\mathrm{m}}-$ maximum fluorescence; $F_{m}{ }^{\prime}$ - the maximum fluorescence yield under light adaptation; $F_{t}$ - the actual fluorescence yield, $F_{v} / F_{m}-m_{a x i m u m}$ quantum yield of PSII; MC - mepiquat chloride; MDA - malondialdehyde; NPQ - nonphotochemical quenching; POD - peroxidase; $\mathrm{q}_{\mathrm{p}}$ - photochemical quenching coefficient; $\mathrm{SE}$ - standard error; SOD - superoxide dismutase; TAA - day interval after anthesis; $\mathrm{Y}_{\mathrm{II}}$ quantum efficiency of PSII.

Acknowledgements: This project was supported by the National Key R\&D Program of China (2020YFD1001000), National Natural Science Foundation of China (31760355), and Program of Youth Science and Technology Innovation Leader of The Xinjiang Production and Construction Corps (2017CB005).

Conflict of interest: The authors declare that they have no conflict of interest.

These authors contributed equally to this work. 
output, and $19.0 \%$ of the global output. Xinjiang is located in the hinterland of the Eurasian continent, with scarce precipitation, strong evaporation, an arid climate, and high dependence on irrigation for agricultural production. In this area, an insufficient water supply is the main obstacle to cotton production. Cotton is a drought-tolerant plant that adapts to dry conditions through significant responses in its internal physiochemical activities (Shareef et al. 2018). Therefore, cotton plant drought tolerance ability and tapping the potential of biological water saving can effectively promote the efficient and sustainable development of cotton in Xinjiang.

Photosynthesis is the prerequisite of cotton yield formation. Chlorophyll (Chl) fluorescence parameters can directly reflect the internal mechanism of plant photosynthesis (Krause and Weis 1991, Baker 2008). During leaf development, the minimal fluorescence yield of the dark-adapted state $\left(\mathrm{F}_{0}\right)$ and nonphotochemical quenching (NPQ) increased with the severity of drought stress (Tang et al. 2007, Yi et al. 2016), and the maximal quantum yield of PSII photochemistry $\left(\mathrm{F}_{\mathrm{v}} / \mathrm{F}_{\mathrm{m}}\right)$, photochemical quenching coefficient $\left(\mathrm{q}_{\mathrm{p}}\right)$, the quantum efficiency of PSII ( $\mathrm{Y}_{\mathrm{II}}$ ), and apparent electron transfer rate (ETR) decreased with drought severity (Zhang et al. 2019). Stomata are the main channels and regulators of $\mathrm{CO}_{2}$ and water vapor transport between higher plants and the outside world. It was found that with the increase of drought stress, the length, width, and opening of stomata decreased, while the density of stomata increased (Wang et al. 2019). Under a normal growth environment, plant antioxidant enzymes superoxide dismutase (SOD, EC 1.15.1.1), peroxidase (POD, EC 1.11.1.7), catalase (CAT, EC 1.11.1.6), and other enzymes are relatively stable. When the plant is under water stress, the superoxide anion and redox substances in the plant increase. At the same time, endogenous antioxidative enzymes ensure an active defense strategy (Bange et al. 2004) to remove the excess active oxygen species in the plant (Miao et al. 2006, Miller et al. 2010, Gao et al. 2014, Subbarao et al. 2000) and enhance the antioxidant capacity of crops under drought stress (McKersie et al. 1993). In addition, drought stress significantly inhibited the production of plant biomass (Wang et al. 2016) and the accumulation of reproductive organ biomass (da Costa and Cothren 2011). Therefore, improving the photosynthetic performance of cotton under water deficit is crucial to improve cotton yield.

As a yield organ, nutrients needed for the growth and development of cotton bolls are mainly provided by photosynthesis of the 'boll-leaf system' (BLS: main stem leaves, boll subtending leaves, and capsule wall) (Mo and Tang 2013). In cotton, the canopy 'boll-leaf' is the main photosynthate 'sink' and 'source', and the 'boll-leaf' relationship reflects the coordination of the vegetative growth and reproductive growth of the cotton plant (Genty et al. 1989, Zhang et al. 2007, Gao et al. 2014). A change in water conditions will change the distribution of photosynthates among the plant components, and at the same time, it will lead to a change in the relationship between the sinks and sources and finally affect the economic yields of crop harvest. The increase in yield depends on the load capacity of leaves under different photosynthetic leaf areas (Luo et al. 2011). However, in the later stage of cotton growth, the leaf area begins declining but the surface area of non-leaf green organs (bracts and bolls) increases. The photosynthetic oxygen-releasing capacity and photosynthetic enzyme activity of non-leaf green organs are relatively stable in the yield-formation stage; therefore, in the later stage of growth, the relative contribution of photosynthesis of non-leaf green organs to the whole cotton plant increases (Hu 2013).

There have been many studies on the response mechanism underlying photoinhibition of photosynthesis in cotton leaves under water stress (Bai et al. 2008, Shahenshah and Isoda 2010, Valladares and Pearcy 2010). However, due to the response of different organs to various water regimes (Zhang et al. 2011a), we hypothesized that drought stress would lead to different adaptability of different components of BLS to water deficit. Therefore, this experiment was conducted to study the effect of drought stress on the mechanism of light protection of cotton sinks and sources and its relationship with the biomass of each component to clarify the differences in the light protection ability of each component and conseqently biological water-saving potential of cotton.

\section{Materials and methods}

Experimental site: The experiment was carried out in 2017-2018 at the Agriculture Test Station of Shihezi University $\left(45^{\circ} 19^{\prime} \mathrm{N}, 86^{\circ} 03^{\prime} \mathrm{E}\right)$, Xinjiang, China. One cotton variety (Gossypium hirsutum L. cv. Xinluzao 45) was sown. The preplanting fertility of $0-20-\mathrm{cm}$ topsoil layer was determined. The texture of the soil from the experimental site was medium loam, and the soil had $\mathrm{pH}$ 7.5, $12.5 \mathrm{~g}$ (organic matter) $\mathrm{kg}^{-1}, 1.45 \mathrm{~g}$ (total nitrogen) $\mathrm{kg}^{-1}, 54.9 \mathrm{mg}$ (alkali nitrogen) $\mathrm{kg}^{-1}, 23.0 \mathrm{mg}$ (available phosphorus) $\mathrm{kg}^{-1}$, and $149 \mathrm{mg}$ (available potassium) $\mathrm{kg}^{-1}$. The mean temperatures during experimental period were in May-September 2017 and 2018, respectively, 21.0 and $18.2^{\circ} \mathrm{C}$ in May, 25.9 and $26.4^{\circ} \mathrm{C}$ in June, 31.3 and $28.3^{\circ} \mathrm{C}$ in July, 27.3 and $27.8^{\circ} \mathrm{C}$ in August, 19.5 and $16.1^{\circ} \mathrm{C}$ in September. The mean rainfall was 5.13 and $5.71 \mathrm{~mm}$ and the mean annual humidity was 31.1 and $30.0 \%$ in 2017 and 2018, respectively.

Experimental design: Generally, a total irrigation amount of 4,800-5,000 $\mathrm{m}^{3} \mathrm{ha}^{-1}$ is required to achieve the seed cotton yield higher than $6,000 \mathrm{~kg} \mathrm{ha}^{-1}$ in the northern Xinjiang region (Luo et al. 2016). A randomized complete block design with four replications was used in this study. The experiment included three drip-irrigation levels, named $\mathrm{W}_{1}$ (conventional drip irrigation, $600 \mathrm{~m}^{3} \mathrm{ha}^{-1}$ of water each time, control), $\mathrm{W}_{2}$ (limited drip irrigation, $480 \mathrm{~m}^{3} \mathrm{ha}^{-1}$ of water each time), and $\mathrm{W}_{3}$ (deficit drip irrigation, $360 \mathrm{~m}^{3} \mathrm{ha}^{-1}$ of water each time). From $45 \mathrm{~d}$ after emergence, eight irrigation treatments were conducted at 10-d intervals. The soil relative water in each plot was measured every after two to three days using a time-domain reflectometer (Trime T3, Germany). Before and after irrigation, the soil relative water content of $\mathrm{W}_{1}$ fluctuated in 49.4-106.0\%, with an average growth period of $75.5 \% ; \mathrm{W}_{2}$ fluctuated within $48.3-96.6 \%$, with an average growth period of 
$70.0 \% ; \mathrm{W}_{3}$ fluctuated within $38.5-92.3 \%$, with an average growth period of $65.2 \%$. In the case of drip irrigation under film, the drip irrigation rates were controlled by a water meter (DN32, Jiangxi Ganma Industry Co., Ltd., China) and switch ball valve. The irrigation was applied on the same dates for all the treatments, and the duration was approximately 10-14 $\mathrm{h}(07: 30-21: 30 \mathrm{~h})$.

Field management: Sowing occurred on 23 April, 2018. Each plastic film was laid with two drip irrigation lines (Beijing Luckrain Inc., China) to plant four rows of cotton with a spacing of $30+60+30 \mathrm{~cm}$. The planting density was 18,000 plants $\mathrm{ha}^{-1}$ (the planting density commonly practiced in this region). Fertilization was performed according to recommended conventional practices. The basal fertilizer consisted of $1,500 \mathrm{~kg}$ (oil residue) $\mathrm{ha}^{-1}$ and $180 \mathrm{~kg} \mathrm{ha}^{-1}$ of additional fertilizer applied with water (first via drip irrigation for $30 \mathrm{~min}$, then via fertilizer), urea and potassium dihydrogen phosphate were applied at $975 \mathrm{~kg}$ $\mathrm{ha}^{-1}$ and $165 \mathrm{~kg} \mathrm{ha}^{-1}$, respectively. $\mathrm{W}_{1}$ was treated with 6 , $11,26,45$, and $120 \mathrm{~g} \mathrm{ha}^{-1}$ of mepiquat chloride (MC) at the cotyledon stage to the two-leaf stage, the 5-7-leaf stage, 2-3 d before the first irrigation, and 5-7 d after topping. No MC was applied before the first and second irrigations under $\mathrm{W}_{2}$ and $\mathrm{W}_{3}$. Artificial topping was carried out on 10 July. Thiabendron ( $80 \%$ thaphthol, $\left.450 \mathrm{~g} \mathrm{ha}^{-1}\right)$ combined with ethephon ( $40 \%$ water; $1,350 \mathrm{ml}$ ) was used as a defoliant on 10 September. Other management practices, such as insect and weed control, were performed according to local agronomic practices.

Chlorophyll (Chl) fluorescence parameters: Four cotton plants from each treatment were randomly marked on the $7,14,21,28,35,42$, and 49 day interval after anthesis (TAA). The first main stem leaves, boll-subtending leaves, and capsule walls with good growth and no pests were marked at the first position of the $3^{\text {rd }}$ fruiting branch $\left(\mathrm{FB}_{3}\right)$. After the gas-exchange parameters were measured, they were brought back to the laboratory under low temperature (in an insulated box). After dark adaptation for $30 \mathrm{~min}$, the Chl fluorescence parameters were measured by a modulated fluorometer ( $P A M$ 100, Walz, Effeltrich, Germany). First, for determination of the $F_{0}$ and maximum fluorescence $\left(\mathrm{F}_{\mathrm{m}}\right)$, actinic light with an intensity of 1,450 $\mu$ mol(photon) $\mathrm{m}^{-2} \mathrm{~s}^{-1}$ was applied. After the fluorescence signal reached a steady state (4-5 $\mathrm{min})$, saturated pulse light was applied for quenching analysis, and the actual fluorescence yield $\left(F_{t}\right)$ and the maximal fluorescence yield of the light-adapted state $\left(\mathrm{F}_{\mathrm{m}}{ }^{\prime}\right)$ were measured at any time. The following $\mathrm{Chl}$ parameters were calculated:

$$
\begin{aligned}
& \mathrm{F}_{\mathrm{v}} / \mathrm{F}_{\mathrm{m}}=\left(\mathrm{F}_{\mathrm{m}}-\mathrm{F}_{0}\right) / \mathrm{F}_{\mathrm{m}} \\
& \mathrm{Y}_{\mathrm{II}}=\left(\mathrm{F}_{\mathrm{m}}{ }^{\prime}-\mathrm{F}_{\mathrm{t}}\right) / \mathrm{F}_{\mathrm{m}}{ }^{\prime} \\
& \mathrm{q}_{\mathrm{p}}=1-\left(\mathrm{F}_{\mathrm{t}}-\mathrm{F}_{0}\right) /\left(\mathrm{F}_{\mathrm{m}}{ }^{\prime}-\mathrm{F}_{0}\right) \\
& \mathrm{NPQ}=\left(\mathrm{F}_{\mathrm{m}}-\mathrm{F}_{\mathrm{m}}{ }^{\prime}\right) / \mathrm{F}_{\mathrm{m}}{ }^{\prime} \\
& \mathrm{ETR}_{\mathrm{II}}=\left(\mathrm{F}_{\mathrm{m}}{ }^{\prime}-\mathrm{F}_{\mathrm{t}}\right) / \mathrm{F}_{\mathrm{m}}{ }^{\prime} \times \mathrm{PAR} \times 0.5 \times 0.84
\end{aligned}
$$

where 0.84 is a common leaf absorptance coefficient for $\mathrm{C}_{3}$ plants and 0.5 assumes an equal distribution of excitation between two photosystems (Björkman and Demmig 1987, Chen and Spreitzer 1992, Björkman and Demmig-Adams 1995, Zhang et al. 2010).

Photosynthetic pigment contents: After each Chl fluorescence test, the leaves and capsule walls were used for the determination of photosynthetic pigment contents, and attention was paid to the preservation of the leaves and capsule walls. Four discs were punched with a hole punch (6 $\mathrm{mm}$ in diameter) and placed into a $15-\mathrm{ml}$ tube with a plug, and the pigment was extracted with $13 \mathrm{ml}$ of $80 \%$ acetone. The tube was covered with a piece of black cloth, placed in the dark, and regularly shaken (extraction was performed for $4 \mathrm{~d}$ until the leaves were milky white) to mix the dipped matter for photosynthetic pigment extraction. A spectrophotometer (UV-2401, Shimadzu, Japan) was utilized to measure the optical density (OD) at wavelengths of 470,645, and $663 \mathrm{~nm}$. The control group was acetone $(80 \%)$. The formulas were as follows:

$\rho(\mathrm{Chl} a)=12.21 \mathrm{OD}_{663}-2.81 \mathrm{OD}_{645}$
$\rho(\mathrm{Chl} b)=20.13 \mathrm{OD}_{645}-5.03 \mathrm{OD}_{663}$
$\rho(\mathrm{Car})=\left[1,000 \mathrm{OD}_{470}-3.27 \rho(\mathrm{Chl} a)-104 \rho(\mathrm{Chl} b)\right] / 229$

(8)

$\mathrm{C}=\rho \mathrm{V}_{\mathrm{t}} /(\mathrm{FV} \times 1,000)$

where $\rho(\mathrm{Chl} a), \rho(\mathrm{Chl} b)$, and $\rho$ (Car) were the chlorophyll $a$, chlorophyll $b$, and Car concentrations [mg ml-1]; $\mathrm{OD}_{470}, \mathrm{OD}_{645}$, and $\mathrm{OD}_{663}$ were the $\mathrm{OD}$ values under wavelengths of 470,645, and $663 \mathrm{~nm}$, respectively; C was the amount of the photosynthetic pigments $[\mathrm{mg} \mathrm{cm}-2]$; $\mathrm{Vt}$ was the total volume of the extracted solution, and FV was the area of the discs $\left[\mathrm{cm}^{2}\right]$.

Hydrogen peroxide $\left(\mathrm{H}_{2} \mathrm{O}_{2}\right)$ and malondialdehyde (MDA) contents and antioxidative enzyme activities: On 7, 14, $21,28,35,42$, and 49 TAA, the first main stem leaves, bollsubtending leaves, and bolls (capsule wall) were marked at the first position of $\mathrm{FB}_{3}$. The activity of superoxide dismutase (SOD) and peroxidase (POD) was determined by the nitroblue tetrazolium method and the guaiacol method (Kochba et al. 1977), respectively. The activity of catalase (CAT), malondialdehyde (MDA), and the content of $\mathrm{H}_{2} \mathrm{O}_{2}$ were assessed by potassium permanganate titration (Kraus and Fletcher 1994), thiobarbituric acid colorimetry (Dhindsa et al. 1981), and redox titration (Nakano and Asada 1987, Bailly et al. 2006), respectively.

Stomatal structure: Three plants per plot were harvested on 21,35 , and 49 TAA and separated into main stem leaves, boll subtending leaves, and bolls (capsule wall) at the first position of $\mathrm{FB}_{3}$. For stomatal density and size determination, two imprints of each sample were made using a transparent nail polish (avoiding veins), and the dried films were removed carefully with a tweezer. The film was mounted on a slide and observed under a microscope (Phoenix 100-3B41L-IPL, Phoenix Optical Group Co., Ltd., China). Six measurements were made for each sample. Stomatal density was determined by counting the number of stomata in a fixed-size field of view. 
Biomass accumulation: Six plants per plot were selected from four replications, bagged, labeled with plastic tags, and transported back to the lab on 7, 14, 21, 28, 35, 42, and 49 TAA. The main stem leaves, boll-subtending leaves, and bolls (capsule wall) at the first position of $\mathrm{FB}_{3}$ were used to determine the green leaf area and biomass. The bolls were divided into capsule walls and seed cotton (fiber). The leaf and capsule walls area were measured using a Licor-3000 instrument (LI-COR Biosciences, Lincoln, USA). Sample leaves, capsule walls, and seed cotton (only at $80^{\circ} \mathrm{C}$ ) were oven dried at $105^{\circ} \mathrm{C}$ for $30 \mathrm{~min}$ and then at $80^{\circ} \mathrm{C}$ for $72 \mathrm{~h}$ to attain a constant mass.

Statistical analysis: The data were processed using Microsoft Excel 2010, and one-way analysis of variance (ANOVA) was performed using SPSS 19.0. The charts were drawn using SigmaPlot 12.5 and Origin 2019b. The significance of differences between means was determined using Duncan's test at the $P<0.05$ level in the same period. The data are presented as the means \pm standard errors.

\section{Results}

Photosynthetic pigments: The proportions of Chl $a, \mathrm{Chl} b$, and Car under different physiological conditions and in different cotton plant organs were not the same (Fig. 1). On 28-35 TAA, the contents of Chl $a$ and $\mathrm{Chl} b$ in different organs were as follows: boll subtending leaves $>$ main stem leaves $>$ capsule wall, while the contents of Car were as follows: boll subtending leaves $>$ capsule wall $>$ main stem leaves. With the decrease in drip irrigation, the contents of Chl $a$ and $\mathrm{Chl} b$ in the main stem leaves, boll subtending leaves, and capsule walls decreased, and the content of Car increased gradually. On 35 TAA, the Chl $a$ content of the main stem leaves, boll subtending leaves, and capsule wall of $\mathrm{W}_{3}$ decreased by 21.8, 20.0, and $15.6 \%$, respectively, compared with $\mathrm{W}_{1}$, and by 17.8 , 20.8 , and $13.5 \%$ compared with $\mathrm{W}_{2}$. The Chl $b$ content of $\mathrm{W}_{3}$ decreased by $25.7,28.5$, and $37.0 \%$ compared with $\mathrm{W}_{1}$, and by $20.2,23.1$, and $31.0 \%$, respectively, compared with those of $\mathrm{W}_{2}$. The Car contents of $\mathrm{W}_{3}$ increased by 42.7 , 9.5, and $31.0 \%$ compared with those of $\mathrm{W}_{1}$ and increased by $17.7,3.9$, and $12.9 \%$, respectively, compared with those of $\mathrm{W}_{2}$.

Chl fluorescence parameters: On 35 TAA, the $F_{v} / F_{m}$ value showed a trend of capsule wall $>$ boll-subtending leaves $>$ main stem leaves (Fig. 2). At the early stage of boll development (7-21 TAA), there was no significant difference in $F_{v} / F_{m}$ between the main stem leaves and the boll subtending leaves. On 35 TAA, $\mathrm{W}_{2}$ decreased the $\mathrm{F}_{\mathrm{v}} / \mathrm{F}_{\mathrm{m}}$ by $1.4 \%$ and increased by $0.3 \%$, respectively, compared with boll-subtending leaves. The $\mathrm{F}_{\mathrm{v}} / \mathrm{F}_{\mathrm{m}}$ values of $\mathrm{W}_{3}$ decreased by 4.9 and $2.4 \%$, respectively, compared to

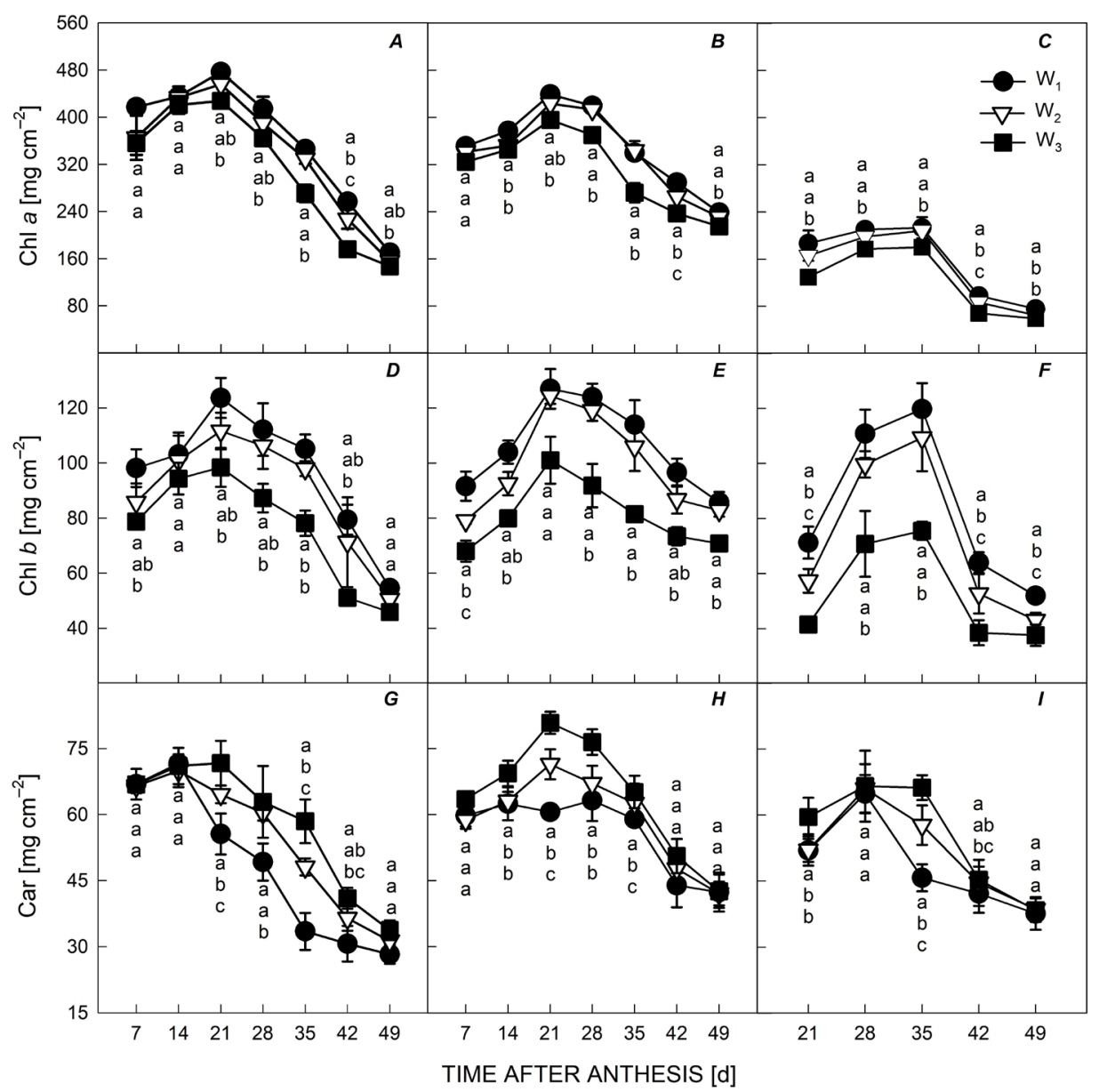

Fig. 1. Changes in chlorophyll (Chl) $a$, Chl $b$, and carotenoid (Car) contents of main stem leaves $(A, D, G)$, boll-subtending leaves $(B, E, H)$, and capsule wall $(C, F, I)$ under conventional drip irrigation $\left(\mathrm{W}_{1}\right)$, limited drip irrigation $\left(\mathrm{W}_{2}\right)$, and deficit drip irrigation $\left(\mathrm{W}_{3}\right)$ with the time after anthesis (TAA). Bars indicate SE $(n=4)$. In Duncan's analysis, the difference between different treatments in the same period was significant $(P<0.05)$. 
$\mathrm{W}_{1}$ and $\mathrm{W}_{2}$ treatments. No significant differences between the values of the $\mathrm{W}_{3}$ and the $\mathrm{W}_{1}$ and $\mathrm{W}_{2}$ treatments were observed.

It can be seen from Fig. 3 that $\mathrm{q}_{\mathrm{p}}$ decreased in the BLS with the change in growth period. On 21-49 TAA, the main stem leaves of $\mathrm{W}_{1}, \mathrm{~W}_{2}$, and $\mathrm{W}_{3}$ showed decreases in $\mathrm{q}_{\mathrm{p}}$ of $43.2,35.5$, and $46.7 \%$, the boll-subtending leaves showed decreases of $43.2,50.1,58.0 \%$, and the capsule wall showed decreases of $49.4,60.6$, and $73.0 \%$, respectively. The trend of ETR $\mathrm{EI}_{\mathrm{II}}$ among organs was different depending on the growth period; the main stem leaves and capsule wall decreased gradually, while that of the boll subtending leaves increased first and then decreased, and the peak value was reached on 21 TAA. With the decrease in irrigation water, ETR $_{\text {II }}$ showed the following trend: $\mathrm{W}_{1}>$ $\mathrm{W}_{2}>\mathrm{W}_{3}$, which indicated that the electron transfer rate of the BLS was seriously affected by deficit irrigation.

Compared to $\mathrm{W}_{1}, \mathrm{~W}_{2}$, and $\mathrm{W}_{3}$ decreased the $\mathrm{Y}_{\mathrm{II}}$ of each component but increased NPQ. On 21-49 TAA, the NPQ of each green organ changed with the growth period in the following order $\mathrm{W}_{1}, \mathrm{~W}_{2}$, and $\mathrm{W}_{3}$ treatments. The NPQ of the main stem leaves increased by $6.2,8.4,12.7 \%$, respectively; the NPQ of boll-subtending leaves increased by $6.8,8.9,9.4 \%$, and the NPQ of capsule wall increased by $42.9,46.9$, and $54.5 \%$, respectively. This indicated that the components of the BLS could alleviate the effect of water stress on PSII and increase the light energy dissipated in the form of heat to protect against light inhibition damage to the photosynthetic apparatus.

Antioxidant enzyme system: $\mathrm{H}_{2} \mathrm{O}_{2}$ is the main product of lipid peroxidation, and the content of MDA reflects the level of lipid peroxidation and the degree of damage to the membrane structure to a certain extent. The $\mathrm{H}_{2} \mathrm{O}_{2}$ and MDA contents in the leaves were always higher than those in the capsule wall, which indicated that the degree of damage in the leaves was higher than that in the capsule wall under water deficit conditions (Fig. 4). On 21-49 TAA, the $\mathrm{H}_{2} \mathrm{O}_{2}$ content of the main stem leaves, boll subtending leaves, and capsule wall increased by 7.4-15.8,
1.4-21.4, and 4.5-17.8\%, respectively, under $\mathrm{W}_{2}$, and by 19.6-72.3, 23.7-48.7, and 5.2-30.2\%, respectively, under $\mathrm{W}_{3}$. The MDA content increased by 5.7-25.7, 1.2-20.4, and $3.0-13.8 \%$ under $\mathrm{W}_{2}$, and by $30.1-45.0,9.6-38.4$, and $7.5-27.0 \%$, respectively, under $\mathrm{W}_{3}$.

The antioxidant enzyme system in plants, which includes SOD, POD, and CAT, can remove the active oxygen produced under adverse environments (Fig. 5). The SOD, POD, and CAT activities of the main stem leaves, boll-subtending leaves, and capsule wall were significantly affected by each treatment and the SOD, POD, and CAT activities of the capsule wall per unit mass were lower than those of the leaves. The SOD and POD activities of each component showed a trend of $\mathrm{W}_{1}<\mathrm{W}_{2}<$ $\mathrm{W}_{3}$. On 21-49 TAA, compared with $\mathrm{W}_{1}$, the SOD activity of the $\mathrm{W}_{2}$ main stem leaves, boll-subtending leaves, and capsule wall increased by 10.7-23.2, 12.4-42.1, and 3.5$37.9 \%$, and those of $\mathrm{W}_{3}$ increased by $18.6-26.1,22.1-70.1$, and $13.8-66.6 \%$, respectively. The POD activity increased by $1.4-9.9,18.3-57.8$, and $19.6-49.6 \%$, respectively, under $\mathrm{W}_{2}$ and by $10.2-55.7,35.6-73.7$, and $29.4-64.6 \%$, respectively, under $\mathrm{W}_{3}$. The results showed that the SOD and POD activity of each component increased during water deficit, which protected the photosynthetic mechanism from drought damage. The activity of CAT varied among the different organs. The main stem leaves and capsule wall showed a tendency of first increasing and then decreasing CAT activity, while the boll-subtending leaves showed a trend of gradually increasing. On 35-49 TAA, the main stem leaves treated with $\mathrm{W}_{2}$ had higher CAT activity.

Stomatal structure: Light micrographs showed significant variation in the stomatal density across the different organs on 35 TAA. For example, cotton leaves had significantly higher stomatal density, while capsule walls had much larger stomata than those of the other organs. Changes in stomatal density and dimensions (length and width) of the BLS components under the different treatments are shown in Table 1. Furthermore, stomatal density

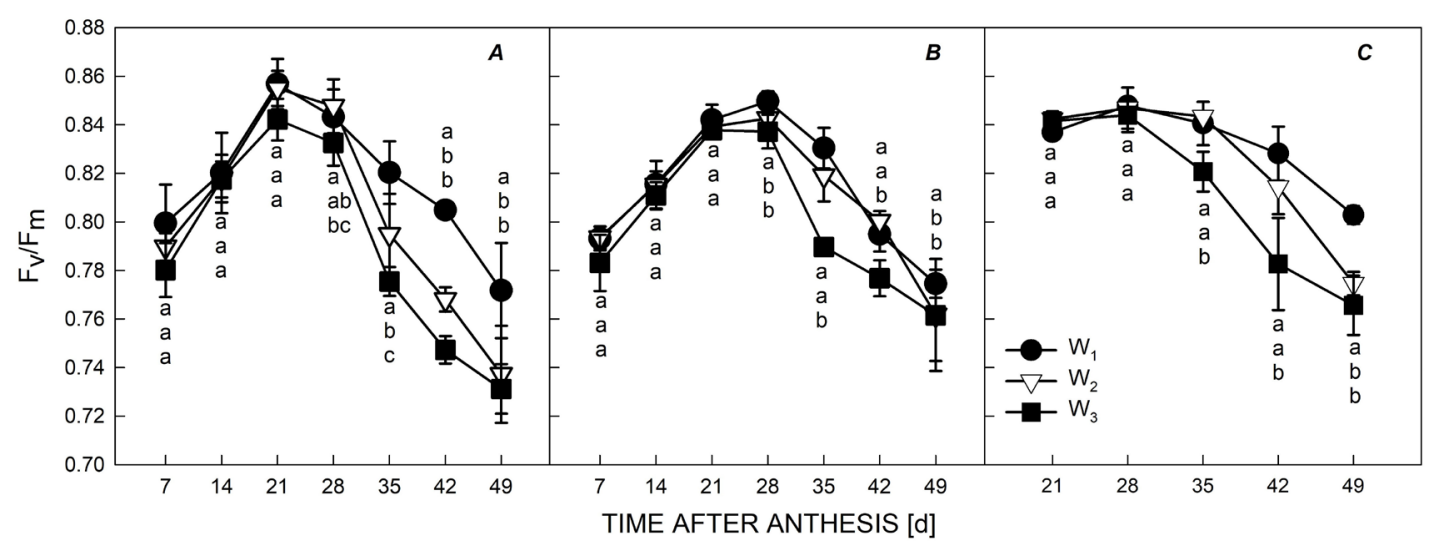

Fig. 2. Changes in the maximal quantum yield of PSII photochemistry $\left(\mathrm{F}_{\mathrm{v}} / \mathrm{F}_{\mathrm{m}}\right)$ of main stem leaves $(A)$, boll subtending leaves $(B)$, and capsule wall $(C)$ under conventional drip irrigation $\left(\mathrm{W}_{1}\right)$, limited drip irrigation $\left(\mathrm{W}_{2}\right)$, and deficit drip irrigation $\left(\mathrm{W}_{3}\right)$ with the time after anthesis (TAA). Bars indicate SE $(n=3)$. In Duncan's analysis, the difference between different treatments in the same period was significant $(P<0.05)$. 


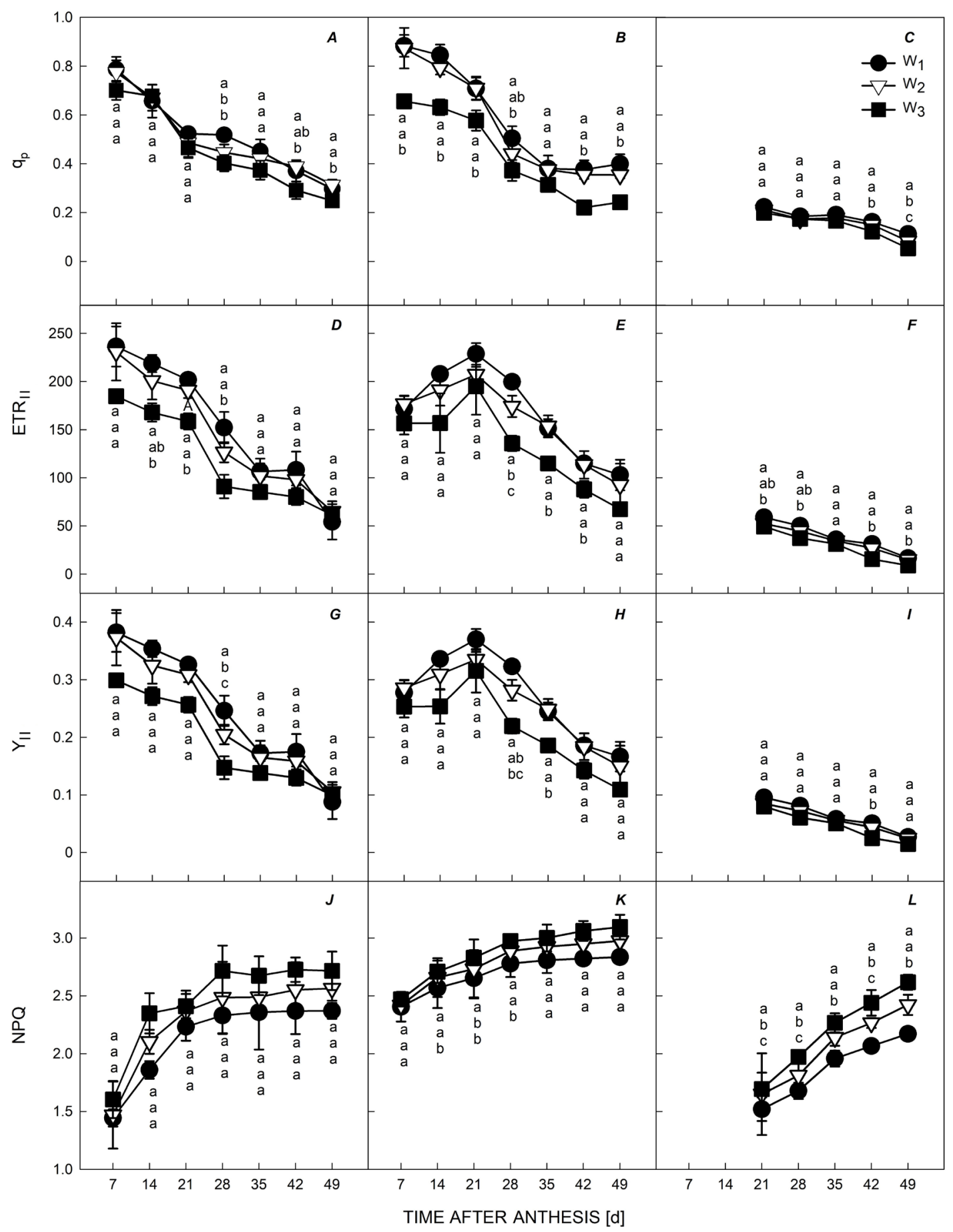

Fig. 3. Changes in the photochemical quenching coefficient $\left(\mathrm{q}_{\mathrm{p}}\right)$, electron transfer rate of PSII (ETR $\left.\mathrm{II}\right)$, quantum efficiency of PSII photochemistry $\left(\mathrm{Y}_{\mathrm{II}}\right)$, and the nonphotochemical quenching $(\mathrm{NPQ})$ of main stem leaves $(A, D, J, I)$, boll-subtending leaves $(B, E, H, K)$, and capsule wall $(C, F, I, L)$ under conventional drip irrigation $\left(\mathrm{W}_{1}\right)$, limited drip irrigation $\left(\mathrm{W}_{2}\right)$, and deficit drip irrigation $\left(\mathrm{W}_{3}\right)$ with the time after anthesis (TAA). Each value represents the mean \pm SE $(n=3)$. In Duncan's analysis, the difference between different treatments in the same period was significant $(P<0.05)$.

and dimensions (length and width) also decreased with decreasing irrigation intensities, with stomatal density showing the trend $\mathrm{W}_{1}<\mathrm{W}_{2}<\mathrm{W}_{3}$, and the stomatal length and width showing the trend $\mathrm{W}_{1}>\mathrm{W}_{2}>\mathrm{W}_{3}$. Compared to $\mathrm{W}_{1}, \mathrm{~W}_{2}$ enhanced the stomatal density of the main stem leaves, boll-subtending leaves, and capsule wall by 13.4 , 23.5 , and $7.5 \%$, and those of $\mathrm{W}_{3}$ were enhanced by 22.1 , 32.7 , and $8.9 \%$ on 35 TAA, respectively. Additionally, $\mathrm{W}_{2}$ significantly reduced the stomatal length of the main stem leaves and boll subtending leaves by 7.2 and $8.9 \%$, 


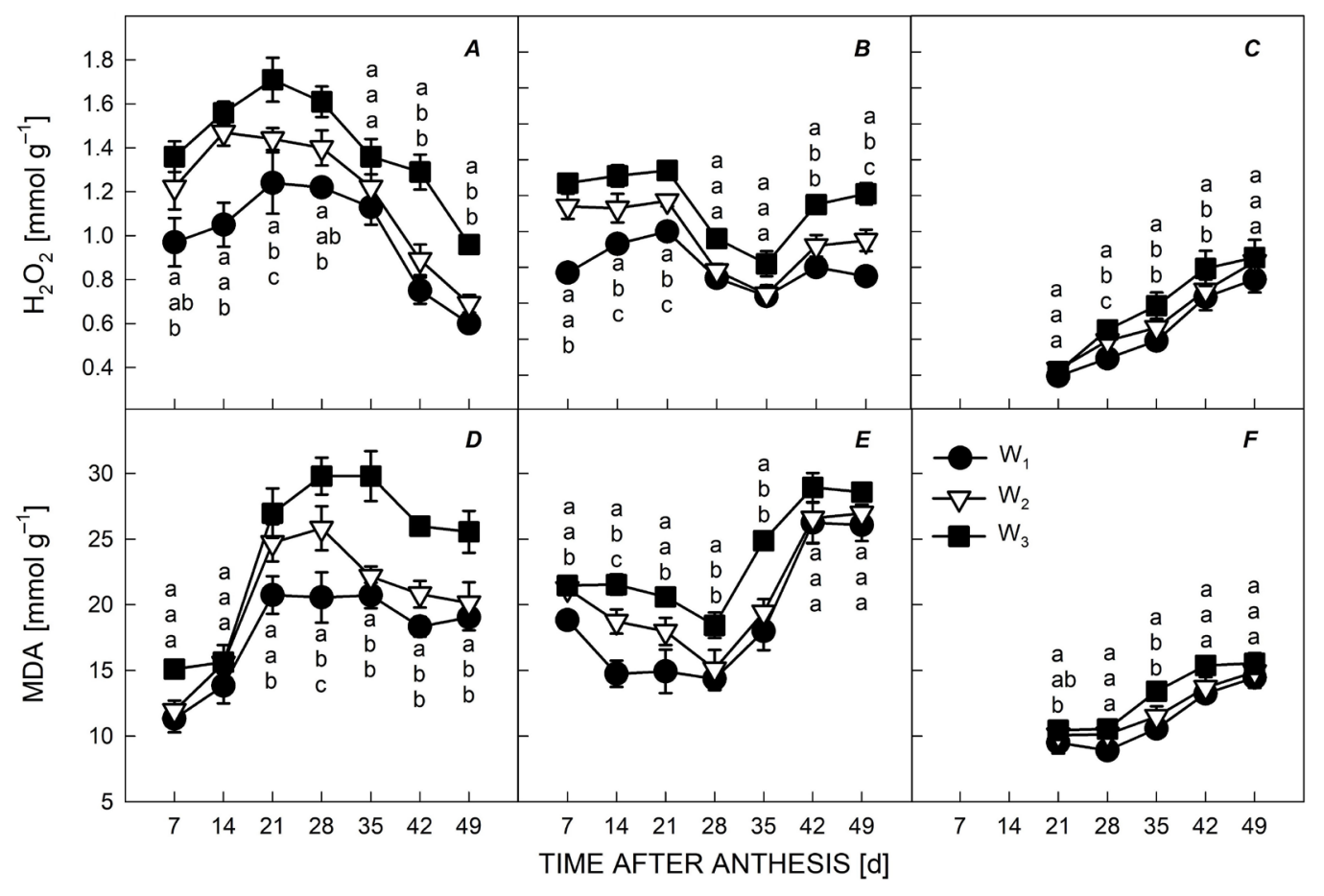

Fig. 4. Changes in hydrogen peroxide $\left(\mathrm{H}_{2} \mathrm{O}_{2}\right)$ and malondialdehyde (MDA) content of main stem leaves $(A, D)$, boll-subtending leaves $(B, E)$, and capsule wall $(C, F)$ under conventional drip irrigation $\left(\mathrm{W}_{1}\right)$, limited drip irrigation $\left(\mathrm{W}_{2}\right)$, and deficit drip irrigation $\left(\mathrm{W}_{3}\right)$ with the time after anthesis (TAA). Each value represents the mean \pm SE $(n=3)$. In Duncan's analysis, the difference between different treatments in the same period was significant $(P<0.05)$.

respectively. The stomatal length of the capsule wall was slightly influenced by the treatments. Compared with $\mathrm{W}_{1}$, the stomata width of the main stem leaves, boll-subtending leaves, and capsule wall decreased by $9.0,10.7$, and $18.1 \%$ in response to $\mathrm{W}_{3}$, respectively. Moreover, drip irrigation slightly influenced the stomatal density and size of each organ on 49 TAA.

Biomass accumulation: The biomass of the main stem leaves, boll-subtending leaves, capsule wall, and seed cotton increased with increasing irrigation and peaked on $28,35,42$, and 49 TAA, respectively (Fig. 6). $\mathrm{W}_{2}$ had no significant difference on 21-49, 28-49, and 35-49 TAA on the biomass of the main stem leaves, boll-subtending leaves, and capsule wall of $\mathrm{W}_{1}$, indicating that limited irrigation $\left(\mathrm{W}_{2}\right)$ mainly affected biomass accumulation by affecting the main stem leaves and boll-subtending leaves on 7-21 TAA but when the cotton bolls developed rapidly, from 21-28 TAA, the BLS mainly affected biomass accumulation by increasing the seed cotton mass. On 21-49 TAA, compared to those of $\mathrm{W}_{3}$, the main stem leaves, boll-subtending leaves, capsule wall, and seed cotton increased by $10.5-15.9,8.0-14.1,4.3-7.6$, and $0.9-$ $24.6 \%$, respectively, under $\mathrm{W}_{2}$ and $14.5-19.3,15.5-22.6$, 6.8-14.8, and 9.2-35.3\%, respectively, under $\mathrm{W}_{1}$.

Principal component analysis: Through principal component analysis (PCA) and calculation (Fig. 7), we determined that 13 physiological indexes of cotton, such as Chl fluorescence parameters, antioxidant enzyme activities,
$\mathrm{H}_{2} \mathrm{O}_{2}$ and MDA contents, and seed cotton mass, were reflected by three principal components (characteristic values: $8.318+2.096+1.022=11.436,8.419+1.944+$ $1.111=11.474,8.181+2.122+1.129=11.432)$ at 88.0 , 88.2 , and $87.9 \%$. The first three principal components provided a high degree of explanation for the total variation in the cotton BLS data. For the main stem leaves and boll subtending leaves of cotton, the first principal component clearly distinguished the water content and the second principal component clearly distinguished the period but for the capsule wall, these contributions were not obvious. For the main stem leaves, the contribution rate of the first principal component was $63.99 \%$, which was characterized by factor variables, such as the contents of Chl $a$, Chl $b$, and Car, $\mathrm{F}_{\mathrm{v}} / \mathrm{F}_{\mathrm{m}}$, SOD and POD activities, and seed cotton mass, having a high load. The contribution rate of the second principal component was $16.1 \%$, which was characterized by a high load of factor variables, such as the MDA and $\mathrm{H}_{2} \mathrm{O}_{2}$ contents, indicating that the $\mathrm{Chl}$ content and antioxidant enzyme system of cotton main stem leaves were greatly affected by water stress, resulting in serious damage to the cell membrane.

The contribution rate of the first principal component of boll-subtending leaves was $64.8 \%$. Chl $a, \mathrm{Chl} b, \mathrm{~F}_{\mathrm{v}} / \mathrm{F}_{\mathrm{m}}$, and $\mathrm{Y}_{\mathrm{II}}$ had higher positive loads, indicating that the change in water content had a major impact on the Chl fluorescence performance of boll-subtending leaves. The contribution of the second principal component was $15.0 \%$, and the SOD and CAT activities and $\mathrm{H}_{2} \mathrm{O}_{2}$ content had higher positive loads, which indicated that the adverse stress caused great 


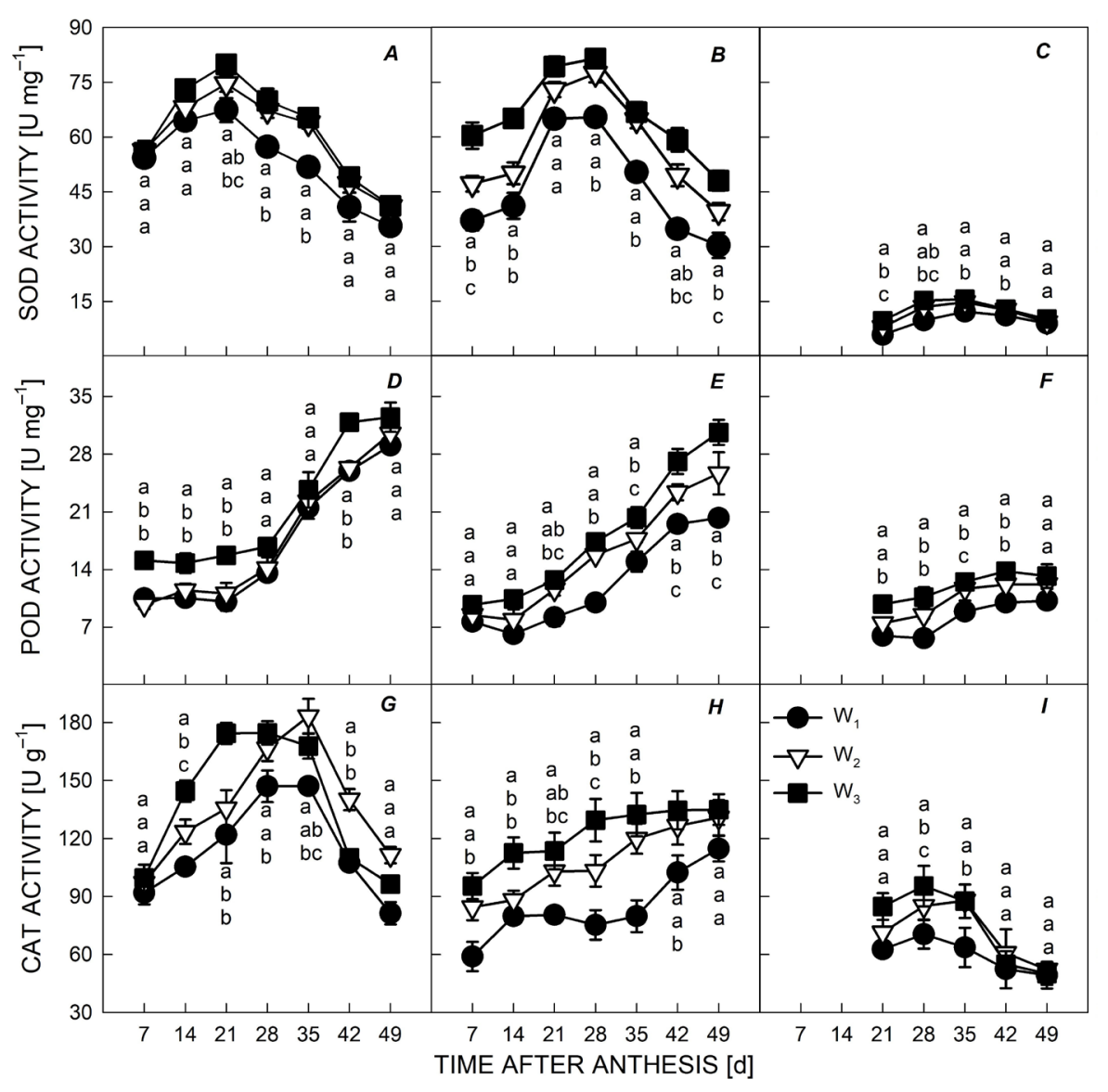

Fig. 5. Changes in the superoxide dismutase (SOD), peroxidase (POD), and catalase (CAT) activity of main stem leaves $(A, D, G)$, boll-subtending leaves $(B, E, H)$, and capsule wall $(C, F, I)$ under conventional drip irrigation $\left(\mathrm{W}_{1}\right)$, limited drip irrigation $\left(\mathrm{W}_{2}\right)$, and deficit drip irrigation $\left(\mathrm{W}_{3}\right)$ with the time after anthesis (TAA). Each value represents the mean \pm SE $(n=3)$. In Duncan's analysis, the difference between different treatments in the same period was significant $(P<0.05)$. damage to the cotton antioxidative enzyme system, so the active oxygen metabolism was out of balance. For the capsule wall, the contribution rate of the first principal component was $62.9 \%$, which was characterized by the higher positive load of factor variables, such as the $F_{v} / F_{m}$, $\mathrm{Y}_{\mathrm{II}}, \mathrm{q}_{\mathrm{p}}$, and the contribution rate of the second principal component was $16.3 \%$, which was characterized by the higher positive load of SOD, POD, and CAT activities, which shows that the Chl fluorescence parameters and cell antioxidative enzymes of the capsule wall of cotton were greatly affected by the different water treatments.

\section{Discussion}

Photoinhibition is the main nonstomatal limitation of plant photosynthesis (Murata et al. 2007). Chl fluorescence parameters are not only closely related to crop drought resistance but also directly reflect the degree of water stress damage to crops (Cao et al. 2017). Drought stress can affect the PSII in crops and thus affect the electron transfer rate and photochemical efficiency, finally leading to a reduction in $\mathrm{CO}_{2}$ assimilation capacity (Zhang et al. 2011b). The $\mathrm{F}_{\mathrm{v}} / \mathrm{F}_{\mathrm{m}}$ after dark adaptation of the plants is an important index to determine whether photoinhibition occurs; ETR II reflects the electron transfer rate of PSII under any light intensity; NPQ reflects the photoprotection ability of PSII; and $\mathrm{q}_{\mathrm{p}}$ represents the magnitude of photosynthetic activity (Li et al. 2014). Previous studies have found that drought stress leads to a decrease in the $F_{v} / F_{m}$, ETR $_{\text {II }}$, and $\mathrm{q}_{\mathrm{p}}$ values of crops and damage to the PSII active center, which inhibits the primary response of photosynthesis. To resist this damage, $\mathrm{q}_{\mathrm{N}}$ and NPQ increase (Zhang et al. 2011b, Guo et al. 2016, Pilon et al. 2018). This study pinpointed that $\mathrm{F}_{\mathrm{v}} / \mathrm{F}_{\mathrm{m}}$ of cotton BSL reached a high level on 21-28 TAA, while $\mathrm{q}_{\mathrm{P}}$ decreased significantly from 7 TAA (capsule wall on 21 TAA) indicating that although cotton could maintain high photochemical efficiency and potential activity of PSII at flowering and boll stage (Guo et al. 2015), the proportion of light energy absorbed by PSII for photochemical reaction decreased (Tao et al. 2013). Under limited irrigation, the $F_{v} / F_{m}$ of the main stem leaves, boll-subtending leaves, and capsule wall remained stable but the actual photochemical efficiency did not decrease significantly, while under deficit irrigation, the $F_{v} / F_{m}$ of the leaves and capsule wall decreased, the NPQ increased correspondingly, and the NPQ of the capsule wall increased significantly. This indicated that there was no significant photoinhibition in the leaves and capsule wall of cotton under limited irrigation, but the electron transfer rate of the PSII reaction center was blocked under deficit irrigation, the share of light energy captured by antenna pigment used for photochemical reactions was reduced, the photochemical activity was reduced, and heat dissipation was enhanced (Gilmore 2001).

The capsule wall initiated the xanthophyll cycle to protect the photosynthetic mechanism from photoinhibition, 


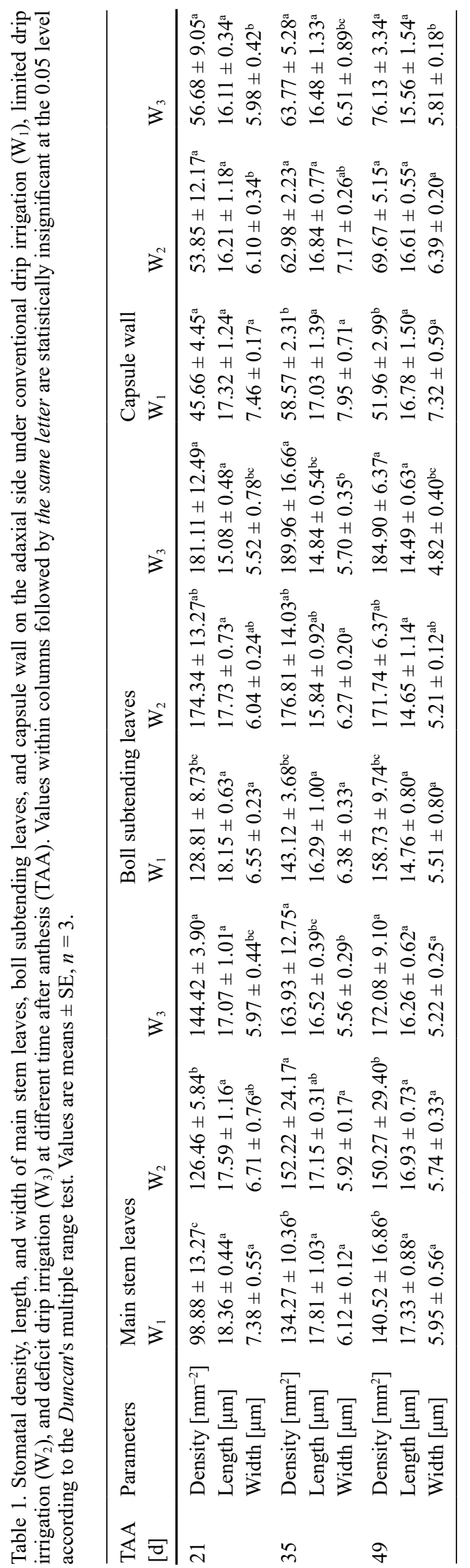

which may be one of the mechanisms of maintaining stable photosynthetic activity. In addition, Car can quench singlet oxygen and protect photosynthetic organs under adversity. On 35-49 TAA, the change in $\mathrm{Y}_{\mathrm{II}}$ in the capsule wall was more stable than that in the leaves and the content of Car increased under water deficit, which indicated that the capsule wall could also reduce the absorption of light energy and enhance the mechanism of light protection by accumulating Car to quench light energy (Hu 2013). The early adaptation of plants to water deficit conditions was mainly reflected in stomatal movement, which affects the photosynthetic carbon assimilation ability of leaves (Cornic 2000). Under long-term drought, stomatal density was positively correlated with stomatal conductance, the carbon assimilation rate, and water-use efficiency (Xu and Zhou 2008), which enabled plants to avoid adverse damage and reduce transpiration, thereby improving their water-use efficiency (Pan et al. 2011). With the decrease in irrigation, the stomatal density of the BLS increased, but the stomatal length decreased (except on the capsule wall), which was consistent with previous research results (Fraser et al. 2009, Yang et al. 2015). The stomatal density of the leaves and capsule wall increased and the stomatal aperture, especially the stomatal width, decreased by reducing the drip irrigation rate, which indicated that drought mainly caused stomatal aperture reduction.

Under adverse conditions, when excess light energy is not completely removed by photoprotection mechanisms such as heat dissipation, ROS accumulation, damage, and increased cell membrane permeability lead to damage from ROS (Yu et al. 2017), affecting plant metabolism. Enzymatic protection systems and antioxidant substances in plants are involved in the removal of ROS (Miao et al. 2006, Miller et al. 2010). Stress can induce plants to initiate their antioxidant enzyme system. SOD, POD, and CAT play roles in photoprotection, remove $\mathrm{H}_{2} \mathrm{O}_{2}$ and other $\operatorname{ROS}\left(\mathrm{O}_{2}^{-}\right)$, reduce the degree of damage to the cell membrane, and thus maintain a high photosynthetic rate (Ullah et al. 2017a). Our experimental results showed that under limited irrigation and deficit irrigation treatments, BLS components with higher MDA and $\mathrm{H}_{2} \mathrm{O}_{2}$ contents and SOD, POD, and CAT activities also showed varying degrees of increases (Li et al. 2019). This shows that water deficit causes membrane lipid peroxidation, and each organ protects itself from harm, increases its antioxidative enzyme activity, and reduces adverse stress, which is consistent with previous research results (Yi et al. 2016, Ullah et al. 2017b).

On 7-21 TAA, the activity of SOD in the main stem leaves and boll-subtending leaves was high. On 35-49 TAA, the activity of POD in the main stem leaves and boll-subtending leaves was also high, indicating that SOD was sensitive to water and played a protective role against water deficit in the early stage of boll development, while POD played a major protective role in the late stage. After 35 TAA, the main stem leaves under limited irrigation showed higher CAT activity, which indicated that cotton leaves could further enhance their active oxygenscavenging ability after moderate drought, resisting the oxidative damage caused by drought stress and improving 


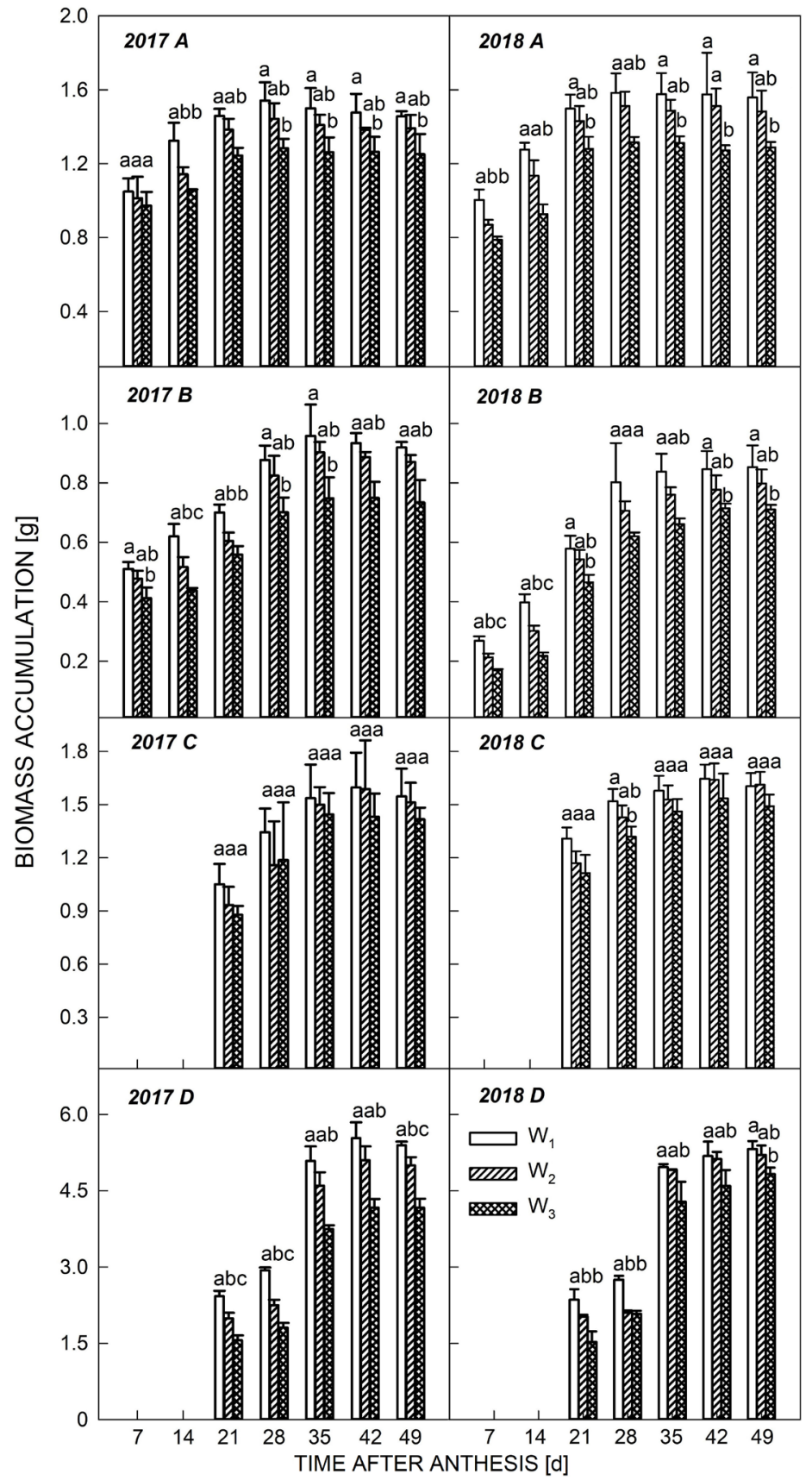

Fig. 6. Changes in biomass accumulation of main stem leaves $(A)$, boll-subtending leaves $(B)$, capsule wall $(C)$, and seed cotton $(D)$ under conventional drip irrigation $\left(\mathrm{W}_{1}\right)$, limited drip irrigation $\left(\mathrm{W}_{2}\right)$, and deficit drip irrigation $\left(\mathrm{W}_{3}\right)$ with the time after anthesis (TAA). Each value represents the mean $\pm \operatorname{SE}(n=3)$. In Duncan's analysis, the difference between different treatments in the same period was significant $(P<0.05)$. the drought tolerance of cotton (Liu et al. 2016). Compared to limited irrigation, deficit irrigation caused more serious damage to the antioxidant enzyme system. The threshold of resistance made it difficult to effectively remove ROS, and thus the drought tolerance of cotton leaves was low. In addition, compared to leaves, the activities of antioxidant enzymes and MDA and $\mathrm{H}_{2} \mathrm{O}_{2}$ contents in the capsule wall were smaller per unit mass; this indicated that the antioxidant system of the capsule wall was weaker, which was consistent with previous research results ( $\mathrm{Hu} 2013$ ).

Water is one of the main factors that affects the growth, development, physiological and biochemical processes of crops, and the water status is manifested in the accumulation of biomass in various plant parts and the formation of yield (Meeks et al. 2019). A change in water conditions affects the dry matter distribution pattern between roots and crowns (Chen et al. 2004). For the cotton BLS, the early effect of irrigation on biomass accumulation was first manifested in the dry matter of leaves on 7-14 TAA but with the growth of the cotton bolls, the influence gradually shifted to the seed cotton mass. On 21-28 TAA, the decrease in irrigation significantly affected plants in the $\mathrm{W}_{2}$ group, but with the growth and development of cotton bolls (Chen et al. 2019), there was no significant difference between the seed cotton biomass under $\mathrm{W}_{1}$ and $\mathrm{W}_{2}$. The possible reasons for this were the limited drip 

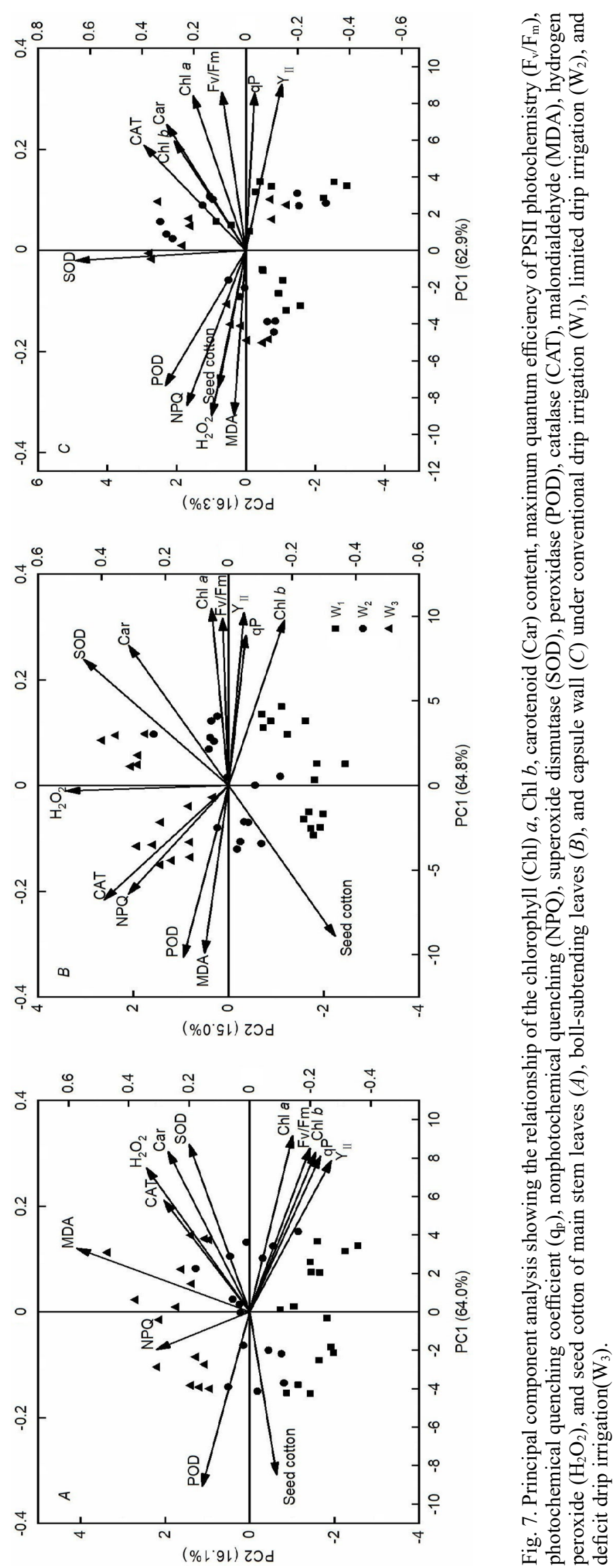
irrigation and the possibility that the small amount of $\mathrm{MC}$ spray stimulated compensatory growth of components of the BLS (Kramer 1983).

Principal component analysis also showed that there was a significant correlation between the Chl fluorescence characteristics of each component of the BLS and the antioxidative enzyme system on the biomass accumulation of seed cotton. For $\mathrm{W}_{3}$, although the contribution of capsule wall biomass accumulation to BLS increased, the seed cotton mass significantly decreased. This was due to the different sensitivities of the different organs to water. When the amount of water was reduced excessively, the distribution of photosynthetic products was hindered, which led to differences in physiological changes (Chaves et al. 2002) and finally affected the development of cotton bolls.

Conclusion: In summary, in the early stage of boll development (on 35 TAA), the $F_{v} / F_{m}$ of capsule wall under the limited irrigation increased by 2.9 and $5.8 \%$ compared to that of boll-subtending leaves and main stem leaves, and that of $\mathrm{F}_{\mathrm{v}} / \mathrm{F}_{\mathrm{m}}$ under deficit irrigation increased by 3.8 and $5.5 \%$ compared to that of fruit branch and main stem leaf, respectively, and the NPQ and Car content increased with decreasing irrigation. On 35 TAA, the stomatal density of the capsule wall was higher over the main stem leaves and boll-subtending leaves and increased with the decrease in irrigation water. The activities of antioxidant enzymes and the MDA and $\mathrm{H}_{2} \mathrm{O}_{2}$ contents were lower than those of the main stem leaves and boll-subtending leaves. Therefore, the capsule wall maintained a high Car content and heat-dissipation ability to quench excess light energy, thus protecting the photosynthetic mechanism. Under water deficit, higher activities of SOD, POD, and CAT and the content of Car resulted in lower accumulation of active oxygen. This further protected the photosynthetic mechanism and let to increased biomass of the cotton BLS.

\section{References}

Bai J., Xu D.H., Kang H.M. et al.: Photoprotective function of photorespiration in Reaumuria soongorica during different levels of drought stress in natural high irradiance. Photosynthetica 46: 232-237, 2008.

Bailly C., Benamar A., Corbineau F., Come D.: Changes in malondialdehyde contents and in superoxide dismutase, catalase, glutathione reductase activities in sunflower seeds related to accelerated seed aging. - Physiol. Plantarum 97: 104-110, 2006.

Baker N.R.: Chlorophyll fluorescence: a probe of photosynthesis in vivo. - Annu. Rev. Plant Biol. 59: 89-113, 2008.

Bange M.P., Milroy S.P., Thongbai P.: Growth and yield of cotton in response to waterlogging. - Field Crop. Res. 88: 129-142, 2004.

Björkman O., Demmig B.: Photon yield of $\mathrm{O}_{2}$ evolution and chlorophyll fluorescence characteristics at $77 \mathrm{~K}$ among vascular plants of diverse origins. - Planta 170: 489-504, 1987.

Björkman O., Demmig-Adams B.: Regulation of Photosynthetic Light Energy Capture, Conversion, and Dissipation in Leaves of Higher Plants. - In: Schulze E.D., Caldwell M.M. (ed.): Ecophysiology of Photosynthesis. Pp. 17-47. Springer,
Berlin-Heidelberg 1995.

Cao C.Y., Dang H.K., Zhang C.L. et al.: [Fluorescence characteristics and drought resistance of wheat under different irrigation regimes.] - J. Triticeae Crop. 37: 1434-1444, 2017. [In Chinese]

Chaves M.M., Pereira J.S., Maroco J. et al.: How plants cope with water stress in the field. Photosynthesis and growth. Ann. Bot.-London 89: 907-916, 2002.

Chen X.Y., Gao Z.H., Liu X.Y. et al.: [Effects of water stress on root/shoot relation and grain yield in winter wheat.] - Acta Agron. Sin. 30: 723-728, 2004. [In Chinese]

Chen Z.K., Niu Y.P., Zhao R.H. et al.: The combination of limited irrigation and high plant density optimizes canopy structure and improves the water use efficiency of cotton. - Agr. Water Manage. 218: 139-148, 2019.

Chen Z.X., Spreitzer R.J.: How various factors influence the $\mathrm{CO}_{2} / \mathrm{O}_{2}$ specificity of ribulose-1,5-bisphosphate carboxylase/ oxygenase. - Photosynth. Res. 31: 157-164, 1992.

Cornic G.: Drought stress inhibits photosynthesis by decreasing stomatal aperture - not by affecting ATP synthesis. - Trends Plant Sci. 5: 187-188, 2000.

da Costa V.A., Cothren J.T.: Drought effects on gas exchange, chlorophyll, and plant growth of 1-methylcyclopropene treated cotton. - Agron. J. 103: 1230-1241, 2011.

Dhindsa R.S., Plumb-Dhindsa P., Thorpe T.A.: Leaf senescence: Correlated with increased levels of membrane permeability and lipid peroxidation, and decreased levels of superoxide dismutase and catalase. - J. Exp. Bot. 32: 93-101, 1981.

Fraser L.H., Greenall A., Carlyle C. et al.: Adaptive phenotypic plasticity of Pseudoroegneria spicata: Response of stomatal density, leaf area and biomass to changes in water supply and increased temperature. - Ann. Bot.-London 103: 769-775, 2009.

Gao F., Chen J., Ma T.T. et al:: The glutathione peroxidase gene family in Thellungiella salsuginea: genome-wide identification, classification, and gene and protein expression analysis under stress conditions. - Int. J. Mol. Sci. 15: 33193335,2014

Genty B., Briantais J.-M., Baker N.R.: The relationship between the quantum yield of photosynthetic electron transport and quenching of chlorophyll fluorescence. - BBA-Gen. Subjects 990: 87-92, 1989.

Gilmore A.M.: Xanthophyll cycle-dependent nonphotochemical quenching in Photosystem II: Mechanistic insights gained from Arabidopsis thaliana L. mutants that lack violaxanthin deepoxidase activity and/or lutein. - Photosynth. Res. 67: 89-101, 2001.

Guo R., Lin T., Tian L. et al.: [Effect of regulated deficit irrigation on photosynthesis and chlorophyll fluorescence characteristics in flowering and boll-forming stages of island cotton.] - Agr. Res. Arid Areas 33: 130-134, 2015. [In Chinese]

Guo Y.Y., Yu H.Y., Kong D.S. et al.: Effects of drought stress on growth and chlorophyll fluorescence of Lycium ruthenicum Murr. seedlings. - Photosynthetica 54: 524-531, 2016.

Hu Y.Y.: [Photosynthetic characteristics and strategies of acclimation of non-foliar organs in cotton (Gossypium spp.) respond to water deficit.] Shihezi University, Shihezi, Xinjiang, China 2013. [In Chinese]

Kochba J., Lavee S., Spiegel-Roy P.: Difference in peroxidase activity and isoenzymes in embryogenic and non-embryogenic 'Shamouti' orange ovular callus lines. - Plant Cell Physiol. 18: 463-467, 1977.

Kramer P.J.: Water deficits and plant growth. - In: Kramer P.J. (ed.): Water Relations of Plants. Pp. 342-389. Academic Press, New York 1983.

Kraus T.E., Fletcher R.A.: Paclobutrazol protects wheat seedlings 
from heat and paraquat injury. Is detoxification of active oxygen involved? - Plant Cell Physiol. 35: 45-52, 1994.

Krause G.H., Weis E.: Chlorophyll fluorescence and photosynthesis: the basics. - Annu. Rev. Plant Phys. 42: 313-349, 1991.

Li P., Zhang Y.J., Liu L.T. et al.: [Effects of water stress on water utilization and leaf photosynthetic characteristics in cotton (Gossypium hirsutum L.) seedlings.] - Cotton Sci. 26: 113121, 2014. [In Chinese]

Li Y.H., Zhang T., Zhang Z.Z., He K.N.: The physiological and biochemical photosynthetic properties of Lycium ruthenicum Murr in response to salinity and drought. - Sci. Hortic.Amsterdam 256: 108530, 2019.

Liu L.T., Sun H.C., Chen J. et al.: Cotton seedling plants adapted to cadmium stress by enhanced activities of protective enzymes. - Plant Soil Environ. 62: 80-85, 2016.

Luo H.H., Zhang Y.L., Zhang W.F.: Effects of water stress and rewatering on photosynthesis, root activity, and yield of cotton with drip irrigation under mulch. - Photosynthetica 54: 65-73, 2016.

Luo X.N., Chen B., Zhang J.S. et al.: [Photosynthetic characteristics and yield of cotton under different nitrogen application rate in Southern Xinjiang.] - Agr. Res. Arid Areas 8: 2679-2685, 2011. [In Chinese]

McKersie B.D., Chen Y., de Beus M. et al.: Superoxide dismutase enhances tolerance of freezing stress in transgenic alfalfa (Medicago sativa L.). - Plant Physiol. 103: 1155-1163, 1993.

Meeks C.D., Snider J.L., Babb-Hartman M.E., Barnes T.L.: Evaluating the mechanisms of photosynthetic inhibition under growth-limiting, early-season water deficit stress in cotton. Crop Sci. 59: 1144-1154, 2019.

Miao Y., Lv D., Wang P. et al.: An Arabidopsis glutathione peroxidase functions as both a redox transducer and a scavenger in abscisic acid and drought stress responses. Plant Cell 18: 2749-2766, 2006.

Miller G., Suzuki N., Ciftci-Yilmaz S., Mittler R.: Reactive oxygen species homeostasis and signalling during drought and salinity stresses. - Plant Cell Environ. 33: 453-467, 2010.

Mo W.C., Tang F.Y.: [Heterosis of dry matter of boll-leaf system in different development stages of upland cotton (Gossypium hirsutum L.).] - Hubei Agric. Sci. 52: 766-770, 2013. [In Chinese]

Murata N., Takahashi S., Nishiyama Y., Allakhverdiev S.I.: Photoinhibition of photosystem II under environmental stress. - BBA-Bioenergetics 1767: 414-421, 2007.

Nakano Y., Asada K.: Purification of ascorbate peroxidase in spinach chloroplasts; its inactivation in ascorbate-depleted medium and reactivation by monodehydroascorbate radical. Plant Cell Physiol. 28: 131-140, 1987.

Pan C.E., Tian L.P., Li Z.Z. et al.: [Studies on drought resistance on anatomical structure of leaves of five poplar clones.] Chin. Agr. Sci. Bull. 27: 21-25, 2011. [In Chinese]

Pilon C., Snider J.L., Sobolev V. et al.: Assessing stomatal and non-stomatal limitations to carbon assimilation under progressive drought in peanut (Arachis hypogaea L.). J. Plant Physiol. 231: 124-134, 2018.

Shahenshah, Isoda A.: Effects of water stress on leaf temperature and chlorophyll fluorescence parameters in cotton and peanut. - Plant Prod. Sci. 13: 269-278, 2010.

Shareef M., Zeng F., Gui D. et al.: Drought induced interactive changes in physiological and biochemical attributes of cotton (Gossypium hirsutum). - Int. J. Agric. Biol. 20: 539-546, 2018.

Subbarao G.V., Chauhan Y.S., Johansen C.: Patterns of osmotic adjustment in pigeonpea - its importance as a mechanism of drought resistance. - Eur. J. Agron. 12: 239-249, 2000.

Tang L.S., Li Y., Zhang J.H.: Physiological and yield responses of cotton under partial rootzone irrigation. - Field Crop. Res. 94: 214-223, 2005.

Tang W., Luo Z., Wen S.M. et al.: [Comparison of inhibitory effects on leaf photosynthesis in cotton seedlings between drought and salinity stress.] - Cotton Sci. 19: 28-32, 2007. [In Chinese]

Tao X.P., Luo H.H., Zhang Y.L. et al.: [Effects of water and nitrogen under root restriction on photosynthetic characters of cotton plants grown with under-mulch drip irrigation.] Acta Ecol. Sin. 33: 3676-3687, 2013. [In Chinese]

Ullah A., Sun H., Yang X.Y., Zhang X.L.: Drought coping strategies in cotton: increased crop per drop. - Plant Biotechnol. J. 15: 271-284, 2017a.

Ullah I., Waqas M., Khan M.A. et al.: Exogenous ascorbic acid mitigates flood stress damages of Vigna angularis. - Appl. Biol. Chem. 60: 603-614, $2017 \mathrm{~b}$.

Valladares F., Pearcy R.W.: Interactions between water stress, sun-shade acclimation, heat tolerance and photoinhibition in the sclerophyll Heteromeles arbutifolia. - Plant Cell Environ. 20: 25-36, 2010.

Wang K.L., Gao Y.Z., Li S. et al.: [Response of leaf stomata and photosynthetic parameters to short-term drought stress in cotton (Gossypium hirsutum L.).] - Chin. J. Eco-Agric. 27: 901-907, 2019. [In Chinese]

Wang R., Gao M., Ji S. et al.: Carbon allocation, osmotic adjustment, antioxidant capacity and growth in cotton under long-term soil drought during flowering and boll-forming period. - Plant Physiol. Bioch. 107: 137-146, 2016.

Xu Z.Z., Zhou G.S.: Responses of leaf stomatal density to water status and its relationship with photosynthesis in a grass. J. Exp. Bot. 59: 3317-3325, 2008.

Yang Z.Q., Tan W., Liu Z.X. et al.: [Effect of soil water stress on stomatal characters of greenhouse tomato leaves.] - Chin. J. Ecol. 34: 1234-1240, 2015. [In Chinese]

Yi X.P., Zhang Y.L., Yao H.S. et al.: Different strategies of acclimation of photosynthesis, electron transport and antioxidative activity in leaves of two cotton species to water deficit. - Funct. Plant Biol. 43: 448-460, 2016.

Yu W.W., Liu Y., Song L.L. et al.: Effect of differential light quality on morphology, photosynthesis, and antioxidant enzyme activity in Camptotheca acuminata seedlings. J. Plant Growth Regul. 36: 148-160, 2017.

Zhang C.M., Shi S.L., Chen J.G.: [Effects of drought stress on chlorophyll fluorescence parameters and lipid peroxidation in alfalfa seedlings.] - Grassl. Turf 39: 18-29, 2019. [In Chinese]

Zhang R.H., Xue J.Q., Pu J. et al.: [Influence of drought stress on plant growth and photosynthetic traits in maize seedlings.] - Acta Agron. Sin. 37: 521-528, 2011b. [In Chinese]

Zhang X., Zhang L., Wang S.H. et al.: [Effect of source-sink regulation on the transportation and allocation of boll-leaf photosynthetic products in cotton.] - Acta Agron. Sin. 33: 843-848, 2007. [In Chinese]

Zhang Y., Zhang Y., Wang Z., Wang Z.: Characteristics of canopy structure and contributions of non-leaf organs to yield in winter wheat under different irrigated conditions. - Field Crop. Res. 123: 187-195, 2011a.

Zhang Y.L., Feng G.Y., Hu Y.Y. et al.: [Photosynthetic activity and its correlation with matter production in non-foliar green organs of cotton.] - Acta Agron. Sin. 36: 701-708, 2010. [In Chinese]

(C) The authors. This is an open access article distributed under the terms of the Creative Commons BY-NC-ND Licence. 